\title{
Expression of metalloproteinase 2 (MMP-2) and metalloproteinase 9 (MMP-9) in THP-1 macrophages cultured with three-dimensional titanium mini-plate systems used for surgical treatment of condylar fractures
}

\author{
Maciej Sikora1,2, Irena Baranowska-Bosiacka² ${ }^{\square}$, Agnieszka Łukomska², Marta Goschorska² \\ and Dariusz Chlubek²
}

\begin{abstract}
'Department of Maxillofacial Surgery, Hospital of the Pomeranian Medical University, Szczecin, Poland

Osteosynthesis with the use of three-dimensional (3D) titanium mini-plate systems in the treatment of condylar fractures is a technique commonly used by maxillofacial surgeons. It is increasingly often mentioned in the literature, especially in the context of bone regeneration. The break in tissue continuity associated with this technique causes activation of pro-inflammatory responses mediated by matrix metalloproteinases MMP-2 and MMP9, enzymes which are also involved in the subsequent bone remodelling. This study showed that the use of 3D titanium mini-plates did not alter the expression of these enzymes in THP-1 macrophages.
\end{abstract}

Key words: three-dimensional (3D) titanium mini-plate systems, condylar fracture; inflammation, macrophages, metalloproteinase 2 (MMP-2), metalloproteinase 9 (MMP-9)

Received: 27 February, 2019; revised: 17 May, 2019; accepted: 02 July, 2019; available on-line: 31 July, 2019

Ðe-mail: ika@pum.edu.pl

Acknowledgments of Financial Support: This study was supported by the statutory budget of the Department of Biochemistry and Medical Chemistry, Pomeranian Medical University

Abbreviations: 3D titanium mini-plates, three-dimensional titanium mini-plates; CAMs, cell adhesion molecules; ECM, extracellular matrix; MMP-2, metalloproteinase 2; MMP-9, metalloproteinase 9; TIMPs, tissue inhibitors of matrix metalloproteinases

\section{INTRODUCTION}

Three-dimensional (3D) titanium mini-plate systems were first presented by M. Farmand in 1992 and are still treated as relatively new (Farmand \& Dupoirieux 1992; Kinra et al., 2017; de Oliveira et al., 2018). The three-dimensionality is understood as their ability to make the stabilized bone elements resistant to twisting, shearing, and bending (de Oliveira et al., 2018). This increased stabilization leads to a reduced infection rate following surgery (Sikora et al., 2018). They also present improved ease of application when compared to the other implants, and, therefore, a shorter duration of surgery (Farmand \& Dupoirieux, 1992).

Implantation of a 3D plate helps to avoid the risks associated with screw loosening in cases of implantation of a single plate, and eliminates the difficulties associated with fixing two plates to the operating field with at least six screws (Cortelazzi et al., 2015; Hakim et al., 2014; Kozakiewicz \& Swiniarski, 2014; Sikora et al., 2016).

Given the above, 3D titanium mini-plates are increasingly popular products used in the treatment of maxil- lofacial trauma to stabilize condylar fractures (Motamedi et al., 2014). They ensure segment stability, facilitate recovery of the operated areas, and increase patient comfort (De Melo et al., 2012). There are several different types of 3D plates used for osteosynthesis of mandibular condylar fractures (Cortelazzi et al., 2015; Hakim et al., 2014; Kozakiewicz \& Swiniarski, 2014; Sikora et al., 2016). In recent years, the technique of $3 \mathrm{D}$ plate usage has been significantly improved by the new technologies, such as computer-aided design/computer-aided manufacture (CAD/CAM) of wafers and three-dimensional (3D) printing (Cornelius et al., 2015; Sugahara et al., 2018). However, the most important condition determining the effectiveness of this type of treatment is the elimination or reduction of the inflammation that results from the activation of the immune system. It is equally important that the applied 3D titanium mini-plates do not interfere with natural regenerative processes following a break in tissue continuity.

Physiological and pathological bone metabolism (e.g. in osteoporosis) (Boyce et al., 2009; Paiva \& Granjeiro, 2017) significantly depends on the proteolysis of the extracellular matrix (ECM) by osteoclasts, large multi-nuclear cells of the myeloid line which attach themselves with pseudopodia to the sites intended for resorption (Datta et al., 2008; Witten \& Huysseune, 2009). The reconstruction of the bone matrix depends on matrix metalloproteinases (MMPs), enzymes involved in bone remodelling, and synthesized by osteoclasts and other cells, such as fibroblasts and macrophages (Cawston \& Wilson, 2006; Lamort et al., 2016).

MMPs are proteins belonging to the family of enzymes including gelatinases, collagenases, stromelysins, matrilysins, secretory MMPs, archetypal MMPs and membrane type I and II MMPs (Nagase et al., 2006; Paiva \& Granjeiro, 2017). MMPs are classified as extracellular enzymes, among which more than 20 subtypes have been identified so far, each encoded by a different gene. Metalloproteinases are assigned to one group of enzymes due to homologous sequences and thus similar structure and enzymatic activity (Lohi et al., 2001; Woessner $\&$ Nagase, 2000). Most of them are excreted out of the cells, some are membrane-bound; they are regarded as endopeptidases and require zinc ions for their enzymatic activity (Woessner \& Nagase, 2000).

ECM components are the main substrates for metalloproteinases, and a structural change of the matrix is the effect of MMP-induced catalysis. MMPs also have other functions, such as regulation of cell activity or participa- 
tion in inflammatory reactions. Many peptides released during partial ECM proteolysis may affect cell activity, but metalloproteinases, in addition to ECM digestion, are also responsible for the catalysis of other biologically active substances, such as growth factors or cell adhesion molecules (CAMs) (McCawley \& Matrisian, 2001). In this way, MMPs play an important role in the regulation of processes such as cell differentiation and migration, regulation of growth factors, angiogenesis and development of inflammation. MMPs also influence cell survival or apoptosis and intercellular communication (Parks et al., 2004; Sternlicht \& Werb, 2001). Metalloproteinases are synthesized in an inactive form and gain catalytic capacity by cleaving a specific part of a precursor enzyme (zymogen) (Yong et al., 1998). Activated metalloproteinases are inhibited by tissue inhibitors of matrix metalloproteinases (TIMPs), which bind them non-covalently. So far, four types of TIMP have been identified (TIMP1-4) (Dzwonek et al., 2004). Regulation of the expression and activity of metalloproteinases is an extremely complex process associated with their potential ability to cause massive degradation of tissues (Overall \& Lopez-Otin, 2002).

The activity and expression of MMPs are controlled mainly at three levels: (1) through the action of TIMP (serum inhibition of MMPs via $\alpha$-2-macroglobulin is also possible); (2) through activation of the proenzyme - initially MMPs are synthesized as inactive zymogens - and (3) through regulation at the gene transcription level (in many cases metalloproteinases can only be expressed through cell activation or simulation). The expression of MMP genes can be stimulated by increased concentrations of growth factors, phorbol esters, oncogene products, and cell-to-cell and cell-to-ECM interactions (Wright \& Harding, 2009). In addition to these three main mechanisms, there are also additional mechanisms regulating the activity of the selected MMP, such as internalization, post-transcriptional modifications (glycosylation in the case of MMP-9), storage (e.g. MMP-9) in granules of neutrophil granulocytes, as well as the compartmentalization and availability of substrates (Yong, 2005).

There is a number of factors activating MMPs (including plasmin, thrombin, interaction of different MMPs) which stimulate inactive proenzyme to autocatalysis, consisting of breaking the bond between the rest of the cysteine and the zinc atom within the enzyme, as a result of which the enzyme gains the full catalytic capacity (Overall, 2002).

The gelatinases examined in this study, i.e. MMP2 and MMP-9, have a specific structure. They contain the N-terminal signal peptide removed immediately after synthesis in the endoplasmic reticulum, and three characteristic tandem repeats in the catalytic domain, thanks to which these enzymes can bind to elastin and collagen, and then carry out their proteolytic decomposition (Sternlicht \& Werb, 2001). Pro-MMP-2 forms a complex of membrane metalloproteinase MT1-MMP (MMP14) and TIMP2, which enables activation of this membrane enzyme on the cell surface and effective proteolysis. ProMMP- 2 can also be bound via the $\alpha 2 \beta 1$ integrin (Dumin et al., 2001). Similarly, the active form of MMP-9 is combined with hyaluronate receptor CD44. Some MMPs can also bind to the cell surface via heparin sulphate chains of membrane proteoglycans, thus catalyzing proteolytic reactions on the cell surface ( $\mathrm{Yu}$ et al., 2002).

Inflammation is a local or systemic reaction of the body to factors that damaged cells and tissues. In other words, it is an unspecific response to homeostasis im- balance (Nowak, 2010). The main effects of the inflammatory reaction include increased blood flow at the site of the irritant's action, higher permeability of capillaries and inflow of leukocytes to the site of damage or infection (Jin et al., 2009). The inflammatory response can also be divided based on the mechanism of reaction into cellular and humoral response. The key cells involved in the cellular response are neutrophilic granulocytes, monocytes, lymphocytes, basophils, eosinophils and platelets belonging to the protein-cellular system. An important role is also played by macrophages, mast cells and fibroblasts (belonging to the pool of connective tissue cells) and endothelial cells. Leukocytes are the first to migrate to the damaged tissue. Then, as a result of the action of certain factors, they are activated, which is followed by their firm adhesion (Kelly et al., 2007). During activation they begin to produce a number of pro-inflammatory substances which aim at eliminating the potential threat to the body. These include interleukins (IL-1 alpha/beta, IL-6, IL-8) and TNF- $\alpha$. Monocytes and granulocytes move from the circulation to the damaged tissues where they transform into phagocytes, i.e. macrophages and microphages, respectively. Then, they phagocytise either microorganisms or apoptotic corpuscles, depending on the aetiology of the inflammation (Kelly et al., 2007).

After eliminating the inflammatory factor, inflammation is cancelled via two mechanisms. The first is the decomposition of the pro-inflammatory factors and discontinuation of the production of new ones (e.g. lowering the activity of kinases involved in the synthesis of proinflammatory kinins). The second is the appearance of substances with anti-inflammatory effects. These include TGF-beta, IL-10 and IL-4, which belong to the group of cytokines, as well as derivatives of polyunsaturated fatty acids such as resolvins, protectins, maresins and lipoxins, which seem to have gained significance in inflammation research in recent years (Nowak, 2010).

A number of reports showed that implantation of biomaterials may cause a release of proinflammatory factors such as cytokines and chemokines and cause activation of the complement system, which adversely affects the host-implant interaction (Refai et al., 2004, Campoccia et al., 2006, Fukano et al., 2006, Suwarsa et al., 2017, Wang et al., 2018, Pettersson et al., 2017). However, in our previous paper (Sikora et al., 2017) 3D titanium mini-plates seemed to be a good alternative to traditional plates, not only due to their desirable technical parameters but also because they did not stimulate the cyclooxygenase-dependent production of prostanoids (prostaglandin E2 and thromboxane B2) in THP-1 monocytes/macrophages, thus limiting the development of inflammation.

Considering a large number of procedures conducted by maxillofacial surgeons using 3D titanium mini-plates in condylar fractures, it seems reasonable to examine whether the plates affect the expression of metalloproteinases involved in the modulation of inflammation and regenerative processes in the bones and soft tissues. The results of such research may improve the assessment of the risk of complications associated with this technique.

\section{MATERIALS AND METHODS}

Reagents. THP-1 monocytic cells were obtained from American Type Culture Collection (ATCC, Rockville, USA). RPMI medium, glutamine, and antibiotics (penicillin and streptomycin), phosphate buffered saline (PBS), 
Table 1. Detailed manufacturer data on the plates and screws used for testing.

\begin{tabular}{|c|c|c|c|c|c|c|c|c|c|}
\hline & \multicolumn{9}{|c|}{ Element [\% weight] } \\
\hline & $\mathrm{Fe}$ & 0 & $\mathrm{~N}$ & $C$ & $\mathrm{H}$ & $\mathrm{Al}$ & V & other & $\mathrm{Ti}$ \\
\hline Ti grade 2 (ASTMF 67:2000) & 0.3 & 0.25 & 0.03 & 0.08 & 0.0125 & & & & rest \\
\hline $\begin{array}{l}\text { Ti6Al4V ELI grade5 (ASTM } \\
\text { F136:2002; ISO5832-3 ) (TAV) }\end{array}$ & 0.25 & 0.13 & 0.05 & 0.08 & 0.012 & $5.5-6.5$ & $3.5-4.5$ & & rest \\
\hline $\begin{array}{l}\text { Ti6Al7Nb (ASTM F1295; } \\
\text { ISO:5832-11) (TAN) }\end{array}$ & 0.25 & 0.20 & 0.05 & 0.08 & 0.009 & $5.5-6.5$ & & $\begin{array}{l}\mathrm{Nb} 6.5-7.5 \\
\mathrm{Ta} \max .0 .5\end{array}$ & rest \\
\hline
\end{tabular}

phorbol 12-myristate 13-acetate (PMA) were purchased from Sigma-Aldrich (Poznań, Poland). Fetal bovine serum was purchased from Gibco (Gibco, Paisley, UK). Metalloproteinase 2 (MMP-2) EIA Kit and metalloproteinase 9 (MMP-9) EIA Kit were purchased from Cayman, USA; Micro BCA Protein Assay kit was purchased from Thermo Scientific, USA.

3D condylar titanium plates. Sets consisting of 3D titanium condylar plates and dedicated screws were obtained from three manufacturers. Plates obtained from DePuySynthes (manufacturer no. 1) were made of pure titanium TiCP - DIN ISO 5832-2, with screws made of titanium alloy (TAN) - DIN 5832-11. Plates manufactured by KLS Martin (manufacturer no. 2) were made of pure titanium - DIN-ISO 5832-2, DIN 17850 and ASTM F 67, with screws of titanium alloy (Ti-6Al-4V) - DIN ISO 5832-3, DIN 17851 and ASTM F 136a. Plates provided by Medartis (manufacturer no. 3) were made of pure titanium ASTM 67, ISO 5832-2, with screws made of titanium alloy ASTM F136, ISO 5832-2. Detailed manufacturer data on the plates and screws used for testing are provided in Table 1. Data on 3D condylar titanium plates and dedicated screws, along with the assigned symbols, are presented in Table 2.

Cell culture and treatment. The experiments were conducted using human macrophages derived from THP-1 cells. Cells were cultured in Roswell Park Memorial Institute medium (RPMI) 1640 (Sigma, St. Louis, $\mathrm{MO}$ ), supplemented with $100 \mathrm{IU} / \mathrm{ml}$ penicillin and 10 $\mu \mathrm{g} / \mathrm{ml}$ streptomycin (Life Technologies, Inc., GrandIsland, NY) in the presence of $10 \%$ heat-inactivated fetal

Table 2. 3D condylar titanium plates and dedicated screws.

\begin{tabular}{|c|c|c|c|}
\hline Item & Manufacturer & Catalog number & Symbol \\
\hline Plate & SYNTHES & 04.503 .834 & S1 \\
\hline Plate & SYNTHES & 04.503 .833 & $\mathrm{~S} 2$ \\
\hline Screw & SYNTHES & $04.503 .406 .01 C$ & S3 \\
\hline Screw & KLS MARTIN & $25-872-09$ & $\mathrm{C} 1$ \\
\hline Plate & KLS MARTIN & 25-283-05 & $\mathrm{C} 2$ \\
\hline Plate & KLS MARTIN & 25-285-05 & $\mathrm{C} 3$ \\
\hline Screw & KLS MARTIN & 25-882-09 & $\mathrm{C} 4$ \\
\hline Screw & MEDARTIS & M-5240.06 & M1 \\
\hline Screw & MEDARTIS & M-5245.06 & M2 \\
\hline Plate & MEDARTIS & $M-4318$ & M3 \\
\hline Plate & MEDARTIS & $M-4852$ & M4 \\
\hline Plate & MEDARTIS & M-4894 & M5 \\
\hline Plate & MEDARTIS & M-4658 & M6 \\
\hline
\end{tabular}

bovine serum (FBS, LifeTechnologies). The cells were cultured in a humidified atmosphere at $37^{\circ} \mathrm{C}$ in $5 \% \mathrm{CO}_{2}$ and the media were refreshed every 48 hours.

Before the experiment, THP-1 cells were plated onto culture flasks at an initial density of $2.5 \times 10^{5}$ cells $/$ well (Corning, Cambridge, MA). The differentiation of THP1 cells into macrophages was achieved by administration of $100 \mathrm{nM}$ PMA for $24 \mathrm{~h}$ (28).

Plate-Induced Inflammatory Reaction in Macrophages. THP-1 macrophages were cultured for $24 \mathrm{~h}$ and $48 \mathrm{~h}$ in RPMI medium with $10 \% \mathrm{FBS}$ with the 3D condylar plates and screws used for surgical treatment of patients with condylar fractures. Plates and the suitable screws were obtained from three different manufacturers: (1) manufacturer no. 1 (S1, S2, S3); (2) manufacturer no. 2 (C1, C2, C3, C4); (3) manufacturer no. 3 (M1, M2, M3, M4, M5, M6); for details see Table 1. Control cells were incubated in RPMI medium with 10\% FBS. After incubation, the cells were harvested by scraping and the pellets were obtained by centrifugation $(800 \times \mathrm{x}, 10$ min). Afterwards, cool PBS was added to the pellets and the samples were stored at $-80^{\circ} \mathrm{C}$ until further analyses. The measurement of protein concentration was conducted using Micro BCA Protein Assay Kit (Thermo Scientific, Rockford, USA). The remaining supernatants were placed in new tubes and stored at $-80^{\circ} \mathrm{C}$ until further analyses, i.e. the extraction and measurement of MMP-2 and MMP-9 expression by ELISA method.

The determination of MMP-2 concentration. MMP-2 expression was determined with a commercially available quantitative ELISA test (Thermo Fisher Scientific, MMP-2 Human ELISA Kit, KHC3081) according to the manufacturer's instructions.

The determination of MMP-9 concentration. MMP-9 expression was determined with a commercially available quantitative ELISA test (Thermo Fisher Scientific, MMP-9 Human ELISA Kit, BMS2016-2) according to the manufacturer's instructions.

Protein concentration. Protein concentration was measured with MicroBCA Protein Assay Kit (Thermo Scientific, Pierce Biotechnology, USA) using a spectrophotometer (UVM340, ASYS).

Immunocytochemical staining. The immunohistochemistry was performed using specific primary antibodies, mouse anti-MMP 2 and mouse anti-MMP 9 (overnight incubation at $4{ }^{\circ} \mathrm{C}$ ) and a secondary antibody conjugated with fluorochrome: anti-mouse IgG-FITC (incubation for $45 \mathrm{~min}$ at room temperature). The nuclei of cells were stained with DAPI. Image acquisition was performed with a fluorescent microscope using filters: 38 HE GFP for green fluorescence and 49 DAPI for blue fluorescence.

Statistical analysis. Statistical analysis of the obtained results was conducted using Statistica 10 software (Statsoft, Poland). The results were expressed as arithmetical means \pm standard deviation (S.D.). The distribution of variables was evaluated using the Shapiro-Wilk W-test. 

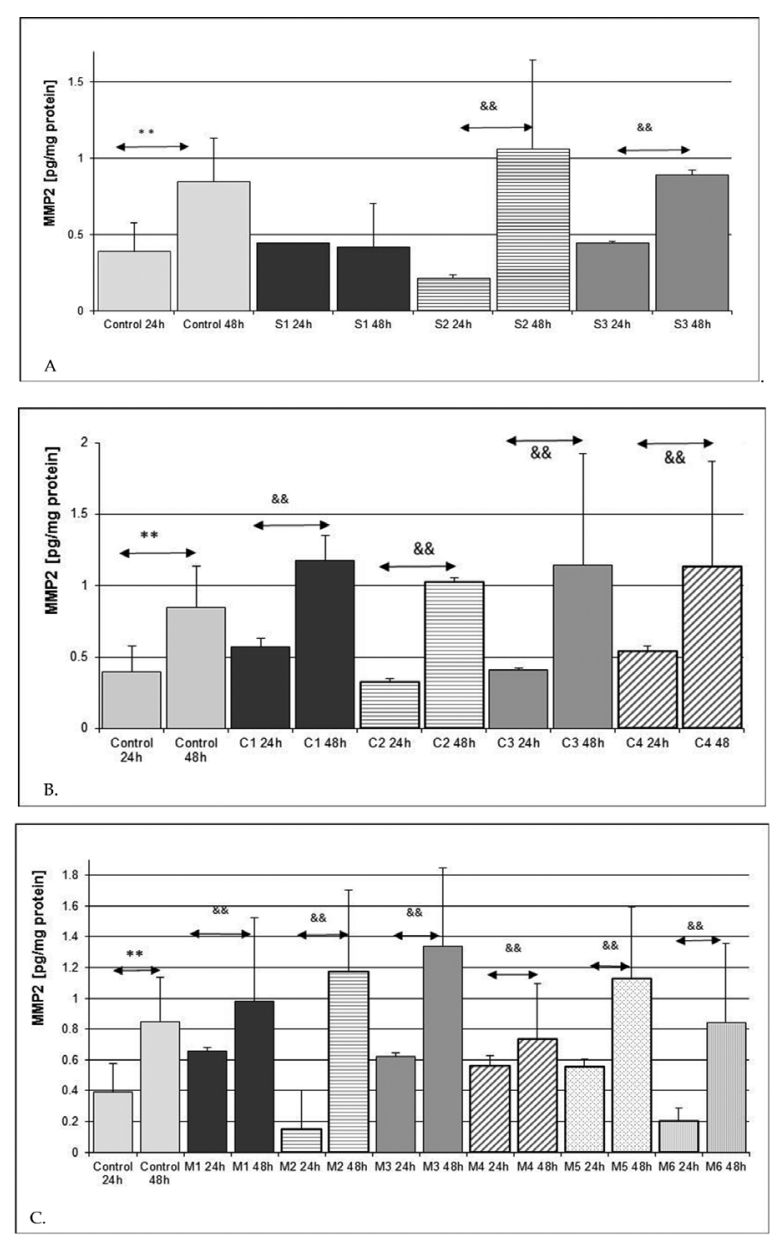

Figure 1. Expression of metalloproteinase 2 (MMP-2) in culture supernatants in macrophages cultured with various 3D plates used for the surgical treatment of condylar fractures.

Macrophages were cultured for $24 \mathrm{~h}$ and $48 \mathrm{~h}$ in RPMI medium with 10\% FBS with various plates: (A) SYNTHES (S1, S2, S3); (B) MARTIN (C1, C2, C3, C4); (C) MEDARTIS (M1, M2, M3, M4, M5, M6); for details see Table 1. After incubation, cells were harvested by scraping and MMP-2 concentration was measured by ELISA method. Experiments were conducted as six separate assays (each assay in three replicates). *Statistically significant differences in comparison to Control $24 \mathrm{~h}(p \leq 0.05) ;{ }^{*}$ Statistically significant differences in comparison to adjacent plate $(p \leq 0.05)$. Control cells were incubated in RPMI medium with $10 \%$ FBS.

Nonparametric tests were used for further analysis because the distribution in most cases deviated from the normal distribution. The results were analyzed by MannWhitney U-test. The level of significance was established at $p<0.05$.

\section{RESULTS}

\section{Expression of MMP-2 in macrophages}

The incubation time of macrophage culture significantly influenced the expression of MMP-2 in control conditions. Enzyme expression increased by more than $100 \%$ in Control $48 \mathrm{~h} v$ s. Control $24 \mathrm{~h}(\phi \leq 0.0001)$.

Incubation of macrophages with SYNTHES 3D plates (S)

The expression of MMP-2 significantly increased for S2 $24 \mathrm{~h} v$ s. S2 $48 \mathrm{~h}$ (increase by ca. $400 \%, p \leq 0.0001$ ) and S3 24 h vs. S3 $48 \mathrm{~h}$ (increase by ca. 100\%, $p \leq 0.0001$ ). No statistically significant differences in enzyme expres-

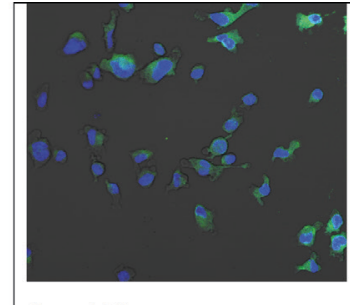

Control 24h
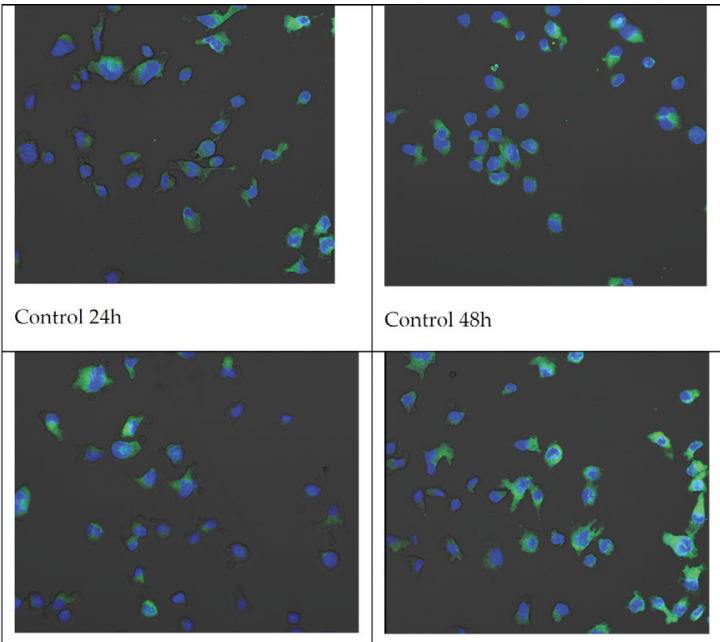

Control $48 \mathrm{~h}$

S1 $24 \mathrm{~h}$

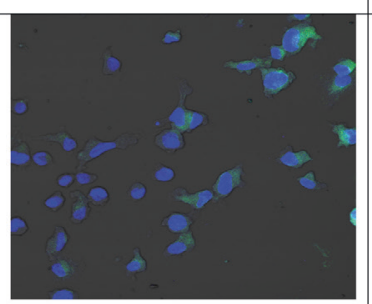

S2 $24 \mathrm{~h}$

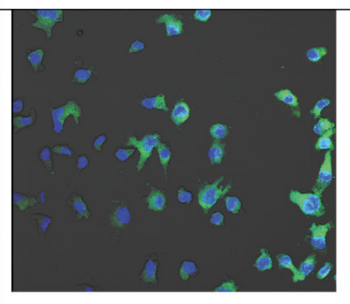

S1 $48 h$

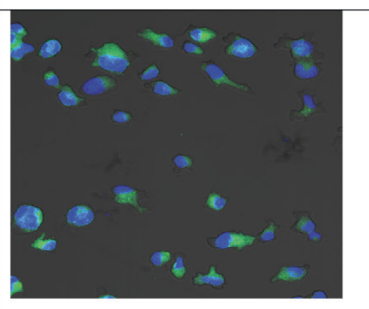

S2 $48 h$

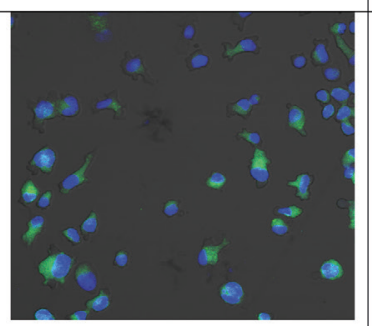

S3 $24 \mathrm{~h}$

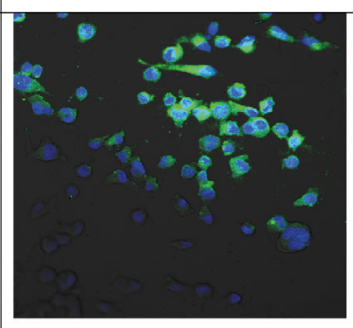

S3 $48 \mathrm{~h}$

Figure 2. Detection of MMP-2 enzyme expression by fluorescence microscopy in macrophages cultured with various 3D plates used for the surgical treatment of condylar fractures.

Macrophages were cultured for $24 \mathrm{~h}$ and $48 \mathrm{~h}$ in RPMI medium with 10\% FBS with various plates: (A) SYNTHES (S1, S2, S3); (B) MARTIN (C1, C2, C3, C4); (C) MEDARTIS (M1, M2, M3, M4, M5, M6); for details see Table 1. Experiments were conducted as six separate assays (each assay in three replicates). The immunohistochemistry was performed using specific primary antibody, mouse anti-MMP 2 (overnight incubation at $4^{\circ} \mathrm{C}$ ) and secondary antibody conjugated with fluorochrome: anti-mouse IgG-FITC (incubation for $45 \mathrm{~min}$ at room temperature). The nuclei of cells were stained with DAPI. Imaging was performed with a fluorescent microscope using filters: $38 \mathrm{HE}$ GFP for green fluorescence and 49 DAPI for blue fluorescence.

sion were observed for S1 $24 \mathrm{~h}$ vs. Control $24 \mathrm{~h}, \mathrm{~S} 2$ $24 \mathrm{~h} v$ s. Control $24 \mathrm{~h}$, and S3 $24 \mathrm{~h}$ vs. Control $24 \mathrm{~h}$.

In none of the observed cases MMP-2 expression in cultures of macrophages incubated with SYNTHES plates was statistically significantly higher than in the Control $48 \mathrm{~h}$ (Fig. 1). Visualization of MMP-2 staining in a confocal microscope confirmed an increase in MMP-2 protein expression in Control 24 vs. Control 48 macrophages. Similar observations were made in macrophages cultured in the presence of the plates S1 $24 \mathrm{~h}$, S2 $24 \mathrm{~h}, \mathrm{~S} 324 \mathrm{~h}$ in comparison to the respective cultures incubated for $48 \mathrm{~h}$ (Fig. 2). 

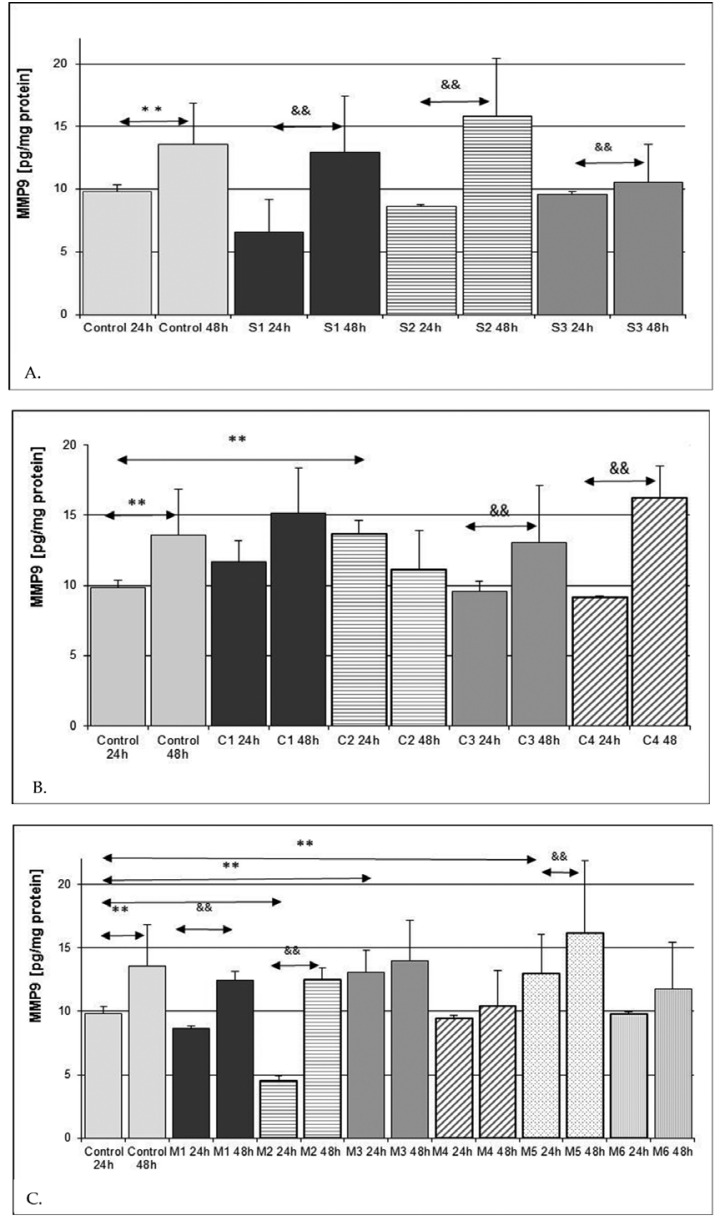

Figure 3. Expression of metalloproteinase 9 (MMP-9) in culture supernatants in macrophages cultured with various $3 \mathrm{D}$ plates used for surgical treatment of condylar fractures.

Macrophages were cultured for $24 \mathrm{~h}$ and $48 \mathrm{~h}$ in RPMI medium with 10\% FBS with various plates: (A) SYNTHES (S1, S2, S3); (B) MARTIN (C1, C2, C3, C4); (C) MEDARTIS (M1, M2, M3, M4, M5, M6) for details see Table 1. After incubation, cells were harvested by scraping and MMP-9 concentration was measured by ELISA method. Experiments were conducted as six separate assays (each assay in three replicates). *Statistically significant differences in comparison to Control $24 \mathrm{~h}(p \leq 0.05)$; ** Statistically significant differences in comparison to adjacent plate $(p \leq 0.05)$. Control cells were incubated in RPMI medium with 10\% FBS.

Incubation of macrophages with MARTIN plates (C)

Incubation with plates for $48 \mathrm{~h}$ caused an increase in the expression of MMP-2 in macrophages. This was found for C1 $24 \mathrm{~h} v s$. C1 $48 \mathrm{~h}$ (increase by $40 \%$, $p=0.0012) ; \mathrm{C} 224 \mathrm{~h}$ vs. C2 $48 \mathrm{~h}$ (increase by $20 \%$, $p \leq 0.0001) ;$ C3 $24 \mathrm{~h}$ vs. C3 $48 \mathrm{~h}$ (increase by $35 \%$, $p \leq 0.001$ ); C4 $24 \mathrm{~h}$ vs. C4 $48 \mathrm{~h}$ (increase by $34 \%$, $p=0.0022)$. However, there was no statistically significant increase in the expression of the tested enzyme protein in macrophages incubated with any of the plates for $24 v s$. Control $24 \mathrm{~h}$. Extension of the incubation time to $48 \mathrm{~h}$ did not cause any significant increase in MMP-2 expression in macrophages for any of the MARTIN plates used as compared to macrophages incubated for $48 \mathrm{~h}$ under control conditions (Control $48 \mathrm{~h}$ ).

Incubation of macrophages with MEDARTIS plates (M)

The incubation time significantly increased the expression of MMP-2 protein in macrophages incubated
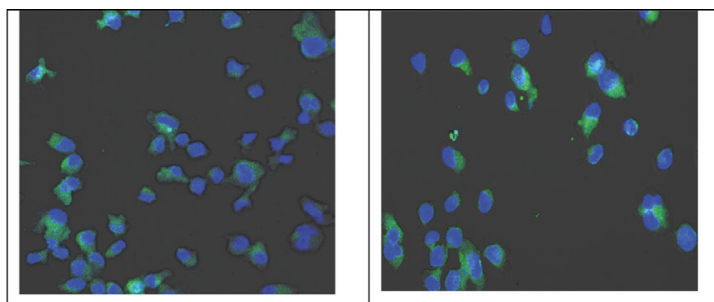

Control 24h

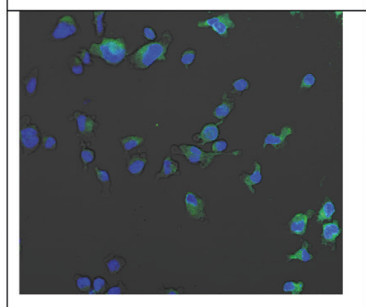

S1 24h

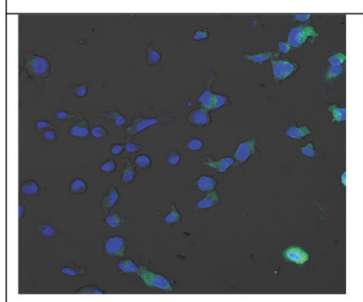

S2 24h

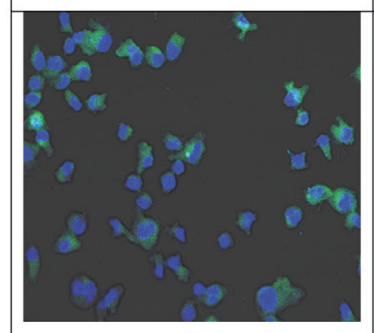

S3 $24 \mathrm{~h}$

Control $48 \mathrm{~h}$

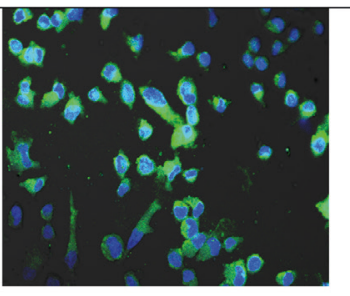

S1 $48 \mathrm{~h}$

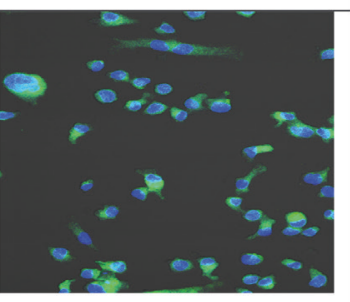

S2 48 h

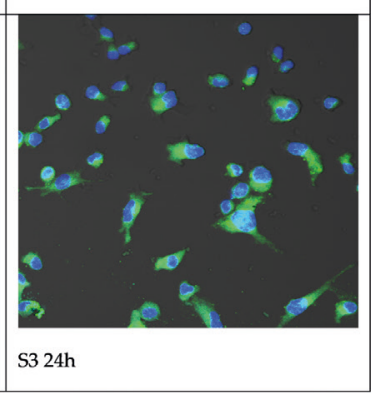

Figure 4. Detection of MMP-9 enzyme expression by fluorescence microscopy in macrophages cultured with various 3D plates used for surgical treatment of condylar fractures.

Macrophages were cultured for $24 \mathrm{~h}$ and $48 \mathrm{~h}$ in RPMI medium with 10\% FBS with various plates: (A) SYNTHES (S1, S2, S3); (B) MARTIN (C1, C2, C3, C4); (C) MEDARTIS (M1, M2, M3, M4, M5, M6) for details see Table 1. Experiments were conducted as six separate assays (each assay in three replicates). The immunohistochemistry was performed using specific primary antibody, mouse anti-MMP 9 (overnight incubation at $4^{\circ} \mathrm{C}$ ) and secondary antibody conjugated with fluorochrome: anti-mouse IgG-FITC (incubation for $45 \mathrm{~min}$ at room temperature). The nuclei of cells were DAPI stained. Imaging was performed with a fluorescent microscope using filters: 38 HE GFP for green fluorescence and 49 DAPI for blue fluorescence.

with plate M1 $24 \mathrm{~h}$ as compared to M1 $48 \mathrm{~h}$ (increase by about 33\%, $p=0.001$ ), M2 $24 \mathrm{~h}$ vs. M2 $48 \mathrm{~h}$ (increase by about $87 \%, p=0.002)$, M2 $24 \mathrm{~h}$ vs. M2 48 h (increase by ca. $87 \%, p=0.002$ ); M3 $24 \mathrm{~h} \mathrm{vs.} \mathrm{M3} 48$ h (increase by ca. $116 \%, p=0.0015)$; M4 24 h vs. M4 $48 \mathrm{~h}$ (increase by ca. $30 \%, p=0.001$ ) and in the case of plate M5 $24 \mathrm{~h}$ vs. M5 $48 \mathrm{~h}$ (increase by approx. $103 \%, p=0.003$ ) and M6 24 h vs. M6 $48 \mathrm{~h}$ (approx. 3 -fold increase, $p=0.005)$. However, in the case of incubation with MEDARTIS plates no significantly higher concentration of MMP-2 was observed in macrophage cultures with the plates as compared to Control $48 \mathrm{~h}$. 


\section{Expression of metalloproteinase 9 (MMP-9) in macrophages}

Longer incubation time caused an increase in the expression of MMP-9 protein in Control $24 \mathrm{~h}$ compared to Control $48 \mathrm{~h}$ (by about 38\%, $p \leq 0.001$ ).

Incubation of macrophages with SYNTHES plates (S)

Expression of MMP-9 protein increased in macrophages incubated with S1 $24 \mathrm{~h} v$ s. S1 $48 \mathrm{~h}$ (by $100 \%$, $p \leq 0.0001$ ) and S2 $24 \mathrm{~h} v$ s. S2 $48 \mathrm{~h}$ (by $80 \%, p \leq 0.0001$ ). Statistically significant differences were not observed in the enzyme expression for S1 $24 \mathrm{~h}$ vs. Control 24, S2 $24 \mathrm{~h}$ vs. Control $24 \mathrm{~h}$, and S3 $24 \mathrm{~h}$ vs. Control $24 \mathrm{~h}$. When incubation time with SYNTHES plates was prolonged to $48 \mathrm{~h}$ for all plates studied, expression of MMP-9 in macrophage cultures was not significantly higher than in the Control $48 \mathrm{~h}$ (Fig. 3). Assessment of the enzyme protein expression carried out with a confocal microscope confirmed the increase of expression in Control $24 \mathrm{~h} v s$. Control $48 \mathrm{~h}$ macrophages. An increase of MMP-9 protein expression was also observed in macrophages incubated with S1 $24 \mathrm{~h}, \mathrm{~S} 224 \mathrm{~h}, \mathrm{~S} 324 \mathrm{~h}$ as compared to the respective cultures for $48 \mathrm{~h}$ incubation time (Fig. 4).

Incubation of macrophages with MARTIN plates (C)

Expression of MMP-9 protein increased in macrophages incubated with $\mathrm{C} 224 \mathrm{~h} v$ s. Control $24 \mathrm{~h}$ (by about $19 \%, p=0.005)$. An increase in protein expression was also observed for C3 $24 \mathrm{~h} v$ s. C3 $48 \mathrm{~h}$ (by about $37 \%, p \leq 0.0022$ ); C4 $24 \mathrm{~h}$ vs. C4 $48 \mathrm{~h}$ (by about $77 \%$, $p=0.003)$. Enzyme protein expression also increased in macrophages incubated with C2 $24 \mathrm{~h}$ vs. Control $24 \mathrm{~h}$. Extension of incubation time to $48 \mathrm{~h}$ did not cause any further statistically significant increase in MMP-9 expression in macrophages for any of the MARTIN plates when compared to Control $48 \mathrm{~h}$.

\section{Incubation of macrophages with MEDARTIS plates (M)}

Expression of MMP-9 protein increased in macrophages incubated with M1 $24 \mathrm{~h} v \mathrm{~s}$. M1 $48 \mathrm{~h}$ (by about $40 \%, p=0.001$ ); and M2 $24 \mathrm{~h} v s$. M2 $48 \mathrm{~h}$ (by about $170 \%, p=0.0042)$. MMP-9 expression decreased in macrophages incubated in M2 $24 \mathrm{~h} v$ s. Control $24 \mathrm{~h}$ (by about $54 \%, p=0.0002$ ) and it decreased for M3 $24 \mathrm{~h}$ plates vs. Control $24 \mathrm{~h}$ (by about 33\%, $p=0.0021$ ) and M5 $24 \mathrm{~h} v$ s. Control $24 \mathrm{~h}$ (by about 32\%, $p=0.0032$ ). However, in the case of incubation with MEDARTIS plates no significantly higher concentration of MMP9 was observed in macrophage cultures with plates as compared to Control $48 \mathrm{~h}$.

\section{DISCUSSION}

The surgical treatment of condylar fractures is inevitably associated with breaks in the continuity of soft tissues, which lead to the excessive synthesis of pro-inflammatory cytokines (IL-1B, IL- 6 and TNF- $\alpha$ ). These cytokines initiate the development of inflammation, which may result in cell degeneration and damage to the surrounding tissues (Choo et al., 2017; Sikora et al., 2017). For this reason, it is important that the plates used by surgeons to stabilize the fracture do not additionally induce inflammatory processes, and at the same time do not disturb the regenerative process.

Surgical treatment of mandibular condyle fractures with the use of metal plates and the associated break in the continuity of tissues is a factor that can initiate the development of inflammation (Paiva \& Granjeiro, 2017; Wagner, 1996; Yan et al., 2016). The matrix metalloproteinases MMP-2 and MMP-9 that were tested in this study also contribute to inflammatory processes in tissues by interacting with chemokines. MMP-2 (similarly to MMP13 and MMP14, but not MMP7-9) removes the $\mathrm{N}$-terminal amino group of chemotactic tetrapeptide of monocyte-chemotactic protein 3 (MCP3). Modified in this way, MCP3 becomes a chemokine receptor antagonist, leading to the extinction of the inflammatory reaction (McQuibban et al., 2000). This is one of the mechanisms determining the chemokine-mediated contribution of MMP-2 to the inflammatory reactions.

A completely different effect occurs as a result of the activation of MMP-9 in the context of inflammatory reactions. MMP-9 removes the six amino acids from the N-terminus of interleukin-8 (IL-8), as a result of which the shortened form of IL- 8 becomes a much stronger stimulus, causing an increased inflow of neutrophils (Van den Steen et al., 2000). It can, therefore, be concluded that increased expression of this enzyme by activation by pro-inflammatory interleukins is characteristic for the initial stage of inflammation (Van den Steen et al., 2000). Increased synthesis of MMP-2 is associated with the extinction of the inflammatory reaction (McQuibban et al., 2000). In our study, the lack of significant changes in the expression of MMP-9 and MMP-2 enzymes in THP1 macrophages incubated in the presence of the examined plates indicates the lack of additional induction of expression of these enzymes by the plates.

Not only cytokines and chemokines influence metalloproteinases. Interaction of MMPs with other molecules in places where the continuity of tissues has been interrupted is also extremely important. Damage resulting from the surgical intervention increases nitric oxide (NO) synthesis by endothelial cells (Berra-Romani et al., 2013). NO activates MMP-9 through S-nitrosylation (Gu et al., 2002), which may cause increased degradation of the extracellular matrix and promote pro-inflammatory processes associated with the activity of MMP-9. The fact that the plates tested by us did not increase the synthesis of the enzyme itself is another proof of their safety. It confirms the results of our earlier studies which showed that the plates do not initiate inflammation via the cyclooxygenase pathway (COXs) (Sikora et al., 2017).

Metalloproteinases are also very important during bone remodelling and regeneration. They are expressed in bone cells, cartilage, inflammatory cells and endothelium. MMPs participate in the regeneration of bones after fractures or other damage mainly by coordinating the mechanism of reconstruction of target matrix proteins (Wang et al., 2013).

Bone reconstruction is accompanied by temporary co-expression of certain enzymatic systems (MMP-2/ MMP14, MMP-9/MMP13) (Colnot et al., 2003; Lehmann et al., 2005). Genetically modified mice without the expression of metalloproteinases (including MMP-2 and MMP-9) showed delayed wound healing, pseudo-orthosis, and even a lack of bone healing (Paiva \& Granjeiro, 2017). Studies on bone regeneration in rodents showed that alveolar process reconstruction after tooth extraction, characterized by three separate stages (exudative, proliferative and generative), take place with the participation of MMP-2, MMP-9 and reversion-inducing cysteine-rich proteins with Kazal motifs (RECK), expressed at all these stages, mainly in osteoblasts, connective tissue and endothelial cells (Accorsi-Mendonca et al., 2008). The implanted biomaterials, implants or 
metal plates should either support the regenerative processes or not interfere with their natural course in the tissue. Demineralized (mainly collagen I) or inorganic bone (hydroxyapatite) implants require MMPs for biomaterial resorption or reconstruction of the surrounding tissue, where MMPs are secreted by macrophages surrounding the transplant (Accorsi-Mendonca et al., 2008; Thais Accorsi-Mendonc et al., 2005; Zambuzzi et al., 2009). During the healing of extensive injuries, the printing of inorganic bone induces increased expression of MMP-2, MMP-9 and vascular endothelial growth factor (VEGF) (Rocha et al., 2014). The results presented in this paper indicate the safety of 3D titanium mini-plates in the treatment of condylar fractures with regard to the expression of MMP-2 and MMP-9.

In this study, the presence of the plates in the cultures of THP-1 macrophages did not increase the expression of MMP-2 or MMP-9. Based on the results of this study, it can be concluded that 3D titanium mini-plates do not increase the inflammatory response in macrophages associated with the activity of the described enzymes. It can also be speculated that they do not affect bone regeneration processes in which MMP-2 and MMP-9 play significant roles.

\section{CONCLUSIONS}

The results presented in this paper confirm that 3D titanium mini-plates do not alter MMP-2 and MMP-9 protein expression in the cultured macrophages.

Author Contributions: M.S was responsible for study design, data collection, data interpretation, literature review and manuscript preparation. I.B-B was responsible for study design, data interpretation, statistical analyses, literature review and manuscript preparation. A.t was responsible for literature review and manuscript preparation. M.G was responsible for manuscript preparation. D. Ch was responsible for funds collection, study design, manuscript preparation.

\section{Conflicts of interest}

The authors declare no conflict of interest.

\section{REFERENCES}

Accorsi-Mendonca T, Paiva KBDS, Zambuzzi WF, Cestari TM, Lara VS, Sogayar MC, Taga R, Granjeiro JM (2008) Expression of matrix metalloproteinases-2 and -9 and RECK during alveolar bone regeneration in rat. J Mol Histol 39: 201-208. https://doi.org/10.1007/ s10735-007-9152-z

Berra-Romani R, Avelino-Cruz JE, Raqeeb A, Della Corte A, Cinelli M, Montagnani S, Guerra G, Moccia F, Tanzi F (2013) Ca $\mathrm{Ca}^{2}$-dependent nitric oxide release in the injured endothelium of excised rat aorta: a promising mechanism applying in vascular prosthetic devices in aging patients. BMC Surg, 13: S40. https://doi.org/10.1186/14712482-13-S2-S40.

Boyce B, Yao Z, Xing L (2009) Osteoclasts have multiple roles in bone in addition to bone resorption. Crit Rev Eukaryot Gene Expr 19: 171-180. https://doi.org/10.1615/CritRevEukarGeneExpr.v19. i3.10.

Campoccia, D, Montanaro L, Arciola CR (2006) The significance of infection related to orthopedic devices and tissues of antibiotics resistance. Biomaterials 27: 2331-2339. https://doi.org/10.1016/j.biomaterials.2005.11.044

Cawston TE, Wilson AJ (2006) Understanding the role of tissue degrading enzymes and their inhibitors in development and disease. Best Pract Res Clin Rheumatol 20: 983-1002. https://doi. org/10.1016/j.berh.2006.06.007.

Choo EH, Lee JH, Park EH, Park HE, Jung NC, Kim TH, Koh YS, Kim E, Seung KB, Park C, Hong KS, Kang K, Song JY, Seo HG, Lim DS, Chang K (2017) Infarcted myocardium-primed dendritic cells improve remodeling and cardiac function after myocardial infarction by modulating the Treg and macrophage polarization.
Circulation 135: 1444-1457. https://doi.org/10.1161/CIRCULATIONAHA.116.023106.

Colnot C, Thompson Z, Miclau T, Werb Z, Helms JA (2003) Altered fracture repair in theabsence of MMP9. Development 130: 4123-4133. https://doi.org/10.1242/dev.00559.

Cornelius CP, Smolka W, Giessler GA, Wilde F, Probst FA (2015) Patient-specific reconstruction plates are the missing link in computer-assisted mandibular reconstruction: A showcase for technical description. J Craniomaxillofac Surg 43: 624-629. https://doi. org/10.1016/j.jcms.2015.02.016.

Cortelazzi R, Altacera M, Turco M, Antonicelli V, De Benedittis M (2015) Development and Clinical Evaluation of MatrixMANDIBLE Subcondylar Plates System (Synthes). Craniomaxillofac Trauma Reconstr 8: 94-99. https://doi.org/10.1055/s-0034-1395382.

Datta HK, Ng WF, Walker JA (2008) Tuck, S.P.; and Varanasi, S.S. The cell biology of bone metabolism. J Clin Pathol 61: 577-587. https://doi.org/10.1136/jcp.2007.048868.

De Melo WM, Antunes AA, Sonoda CK, Hochuli-Vieira E, Gabrielli MA, Gabrielli MF (2012). Mandibular angle fracture treated with new three-dimensional grid miniplate. J Craniofac Surg 23: 416-417. https://doi.org/10.1097/SCS.0b013e31825dad8f.

Dumin JA, Dickeson SK, Stricker TP, Bhattacharyya-Pakrasi M, Roby JD, Santoro SA, Parks WC (2001) Pro-collagenase-1 (Matrix Metalloproteinase-1) binds the $\alpha 2 \beta 1$ integrin upon release from keratinocytes migrating on type I collagen. I Biol Chem 276: 29368-29374. https://doi.org/10.1074/jbc.M104179200.

Dzwonek J, Rylski M, Kaczmarek L (2004) Matrix metalloproteinases and their endogenous inhibitors in neuronal physiology of the adult brain. FEBS Lett 567: 129-35. https://doi.org/10.1016/j.febslet.2004.03.070.

Farmand M, Dupoirieux L (1992) The value of three dimensional plates in maxillofacial surgery. Rev Stomatol Chir Maxillofac 92: 353357.

Fukano Y, Knowles NG, Usui ML, Underwood RA, Hauch KD, Marshall AJ, Ratner BD, Giachelli C, Carter WG, Fleckman P, Olerud JE (2006) Characterization of an in vitro model for evaluating the interface between skin and percutaneous biomaterials. Wound Repair Regen 14: 484-491. https://doi.org/10.1111/j.17436109.2006.00138.x

Gu Z, Kaul M; Yan B, Kridel SJ, Cui J, Strongin A, Smith JW, Liddington RC, Lipton SA (2002) S-nitrosylation of matrix metalloproteinases: signaling pathway to neuronal cell death. Science 297: 1186-1190. https://doi.org/10.1126/science.1073634

Hakim SG, Wolf M, Wendlandt R, Kimmerle H, Sieg P, Jacobsen HC (2014) Comparative biomechanical study on three miniplates osteosynthesis systems for stabilisation of low condylar fractures of the mandible. Br J Oral Maxillofac Surg 52: 317-322. https://doi. org/10.1016/j.bjoms.2014.02.002.

Jin Y, Arita M, Zhang Q, Saban DR, Chauhan SK, Chiang N, Serhan CN, Dana R (2009) Anti-angiogenesis effect of the novel anti-inflammatory and pro-resolving lipid mediators. Invest. Ophthalmol Vis Sci 50: 4743-4752. https://doi.org/10.1167/iovs.08-2462.

Kelly M, Hwang JM, Kubes P (2007) Modulating leukocyte recruitment in inflammation. J Allergy Clin Immunol 120: 3-10. https://doi. org/10.1016/j.jaci.2007.05.017.

Kinra PK, Jayakumar K, Soumithran CS, Michael MJ, Passi D, Singh M (2017). Comparative evaluation of bite force analytical study following mandibular osteosynthesis using three dimensional and conventional locking miniplates. Natl J Maxillofac Surg 8: 34-40. https://doi.org/10.4103/njms.NJMS_76_16)

Kozakiewicz M, Swiniarski J, (2014) "A" shape plate for open rigid internal fixation of mandible condyle neck fracture. I Craniomaxillofac Surg 42: 730-737. https:// doi.org/10.1016/j.jcms.2013.11.003.

Lamort AS, Gravier R, Laffitte A, Juliano L, Zani ML, Moreau T (2016) New insights into the substrate specificity of macrophage elastase MMP-12. Biol Chem 397: 469-484. https://doi.org/10.1515/ hsz-2015-0254.

Lehmann W, Edgar CM, Wang K, Cho TJ, Barnes GL, Kakar S, Graves DT, Rueger JM, Gerstenfeld, LC, Einhorn, TA (2005) Tumor necrosis factor alpha (TNF-alpha) coordinately regulates the expression of specific matrix metalloproteinases (MMPS) and angiogenic factors during fracture healing. Bone 36: 300-310. https://doi. org/10.1016/j.bone.2004.10.010.

Lohi J, Wilson CL, Roby JD, Parks WC (2001) Gene, H.E. Epilysin, a Novel Human Matrix Metalloproteinase (MMP-28) Expressed in testis and keratinocytes and in response to injury. J Biol Chem 276: 10134-10144. https://doi.org/10.1074/jbc.M001599200.

McCawley LJ, Matrisian LM (2001) Matrix metalloproteinases: they're not just for matrix anymore! Curr Opin Cell Biol England 13: 534 540. PMID: 11544020

McQuibban GA, Gong JH, Tam EM, McCulloch CA, Clark-Lewis I, Overall CM (2000) Inflammation dampened by gelatinase A cleavage of monocyte chemoattractant protein-3. Science 289: 1202-1206. https://doi.org/10.1126/science.289.5482.1202.

Motamedi MH, Dadgar E, Ebrahimi, A, Shirani, G, Haghighat A, Jamalpour MR (2014). Pattern of maxillofacial fractures: A 5-year 
analysis of 8818 patients. I Trauma Acute Care Surg 77: 630-634. https://doi.org/10.1097/TA.0000000000000369.

Nagase H, Visse R, Murphy G (2006) Structure and function of matrix metalloproteinases and TIMPs. Cardiovasc Res England 69: 562-573. https://doi.org/10.1016/j.cardiores.2005.12.002.

Nowak JZ (2010) Anti-inflammatory pro-resolving derivatives of omega-3 and omega-6 polyunsaturated fatty acids. Postepy Hig Med Dosw 64: 115-132. PMID: 20354260

de Oliveira JCS, Moura LB, de Menezes JDS, Gabrielli MAC, Pereira Filho VA, Hochuli Vieira E (2018) Three dimensional strut plate for the treatment of mandibular fractures: a systemic review. Int J Oral Maxillofac Surg 47: 330-338. https://doi.org/10.1016/j. ijom.2017.08.009

Overall CM (2002) Molecular determinants of metalloproteinase substrate specificity: matrix metalloproteinase substrate binding domains, modules, and exosites. Mol Biotechnol 22: 51-86. https://doi. org/10.1385/MB:22:1:051.

Overall CM, Lopez-Otin C (2002) Strategies for MMP inhibition in cancer: innovations for the post-trial era. Nat Rev Cancer 2: 657-672. https://doi.org/10.1038/nrc884.

Paiva KBS, Granjeiro JM (2017) Matrix Metalloproteinases in Bone Resorption, Remodeling, and Repair. Prog Mol Biol Transl Sci 148: 203-303. https://doi.org/10.1016/bs.pmbts.2017.05.001.

Parks WC, Wilson CL, Lopez-Boado YS (2004) Matrix metalloproteinases as modulators of inflammation and innate immunity. Nat Rev Immunol England 4: 617-629. https://doi.org/10.1038/nri1418.

Pettersson M, Kelk P, Belibasakis GN, Bylund D, Molin Thorén M, Johansson A (2017) Titanium ions form particles that activate and execute interleukin-1 $\beta$ release from lipopolysaccharide-primed macrophages. J Periodontal Res 52: 21-32. https://doi.org/10.1111/ jre.12364

Refai AK, Textor M, Brunette DM, Waterfield JD (2004) Effect of titanium surface topography on macrophage activation and secretion of proinflammatory cytokines and chemokines. J Biomed Mater Res A 70: 194-205. https://doi.org/10.1002/jbm.a.30075

Rocha CA, Cestari, TM, Vidotti, HA, De Assis GF, Garlet GP, Taga R (2014) Sintered anorganic bone graft increases autocrine expression of VEGF, MMP-2 and MMP-9 during repair of critical-size bone defects. J Mol Histol 45: 447-461. https://doi.org/10.1007/s10735014-9565-4.

Sikora M, Goschorska M, Baranowska-Bosiacka I, Chlubek D (2017) In vitro effect of $3 \mathrm{~d}$ plates used for surgical treatment of condylar fractures on prostaglandin $\mathrm{E}_{2}\left(\mathrm{PGE}_{2}\right)$ and thromboxane $\mathrm{B}_{2}\left(\mathrm{TXB}_{2}\right)$ concentration in THP-1 macrophages. Int J Mol Sci 18: 2638. https:// doi.org/10.3390/ijms18122638.

Sikora M, Sielski M, Stapor A, Chlubek D (2016) Use of the Delta plate for surgical treatment of patients with condylar fractures. J Craniomaxillofac Surg 44: 770-774. https://doi.org/10.1016/j. jcms.2016.04.008.

Sikora M, Olszowski T, Chlubek D (2018) Current views on the treatment of condylar fractures. Pomeranian J Life Sci 64: 14-23

Sternlicht MD, Werb Z (2001) How matrix metalloproteinases regulate cell behavior. Annu Rev Cell Dev Biol 17: 463-516. https://doi. org/10.1146/annurev.cellbio.17.1.463.

Sugahara K, Katsumi Y, Koyachi M, Koyama Y, Matsunaga S, Odaka K, Abe S, Takano, M, Katakura A (2018) Novel condylar repositioning method for 3D-printed models. Maxillofac Plast Reconstr Surg 40: 4. https://doi.org/10.1186/s40902-018-0143-7.
Suwarsa O, Rahardjo RM, Sutedja E, Dharmadji HP, Hindritiani R, Gunawan H (2017) Systemic contact dermatitis due to corrosion of titanium-coated nickel and cobalt bone plate fixation: A case report. Medicine (Baltimore) 96: e9120. https://doi.org/10.1097/ MD.0000000000009120

Thais Accorsi-Mendonc T, Zambuzzi WF, Paiva KBS, Lauris JRP, Cestari TM, Rumio Taga R, Granjeiro JM (2005) Expression of metalloproteinase 2 in the cell response to porous demineralized bovine bone matrix. J Mol Histol 36: 311-316. https://doi.org/10.1007/ s10735-005-7018-7019.

Van den Steen PE, Proost P, Wuyts A, Van Damme J, Opdenakker G (2000) Neutrophil gelatinase B potentiates interleukin-8 tenfold by aminoterminal processing, whereas it degrades CTAP-III, PF-4, and GRO-alpha and leaves RANTES and MCP-2 intact. Blood 96: 2673-2681. PMID: 11023497

Wagner JA (1996) Is IL-6 both a cytokine and a neurotrophic factor? J Exp Med 183: 2417-2419. https://doi.org/10.1084/jem.183.6.2417

Wang X, Yu YY, Lieu S, Yang F, Lang J, Lu C, Werb Z, Hu D, Miclau T, Marcucio, Colnot C (2013) MMP9 regulates the cellular response to inflammation after skeletal injury. Bone 52: 111-119. https://doi.org/10.1016/j.bone.2012.09.018.

Wang J, Meng F, Song W, Jin J, Ma Q, Fei D, Fang L, Chen L, Wang Q, Zhang Y (2018) Nanostructured titanium regulates osseointegration via influencing macrophage polarization in the osteogenic environment. Int J Nanomedicine 13: 4029-4043. https://doi.org/10.2147/ IJN.S163956

Witten PE, Huysseune A (2009) A comparative view on mechanisms and functions of skeletal remodelling in teleost fish, with special emphasis on osteoclasts and their function. Biol Rev 84: 315-346. https://doi.org/10.1111/j.1469-185X.2009.00077.x.

Woessner JF, Nagase H (2000) Matrix Metalloproteinases and TIMPs In Protein Profile, Sheterline P, ed, Oxford University Press, Oxford.

Wright JW, Harding JW (2009) Contributions of matrix metalloproteinases to neural plasticity, habituation, associative learning and drug addiction. Neural Plast. https://doi.org/10.1155/2009/579382.

Yan N, Liu Y, Liu S, Cao S, Wang F, Wang Z, Xi S (2016) Fluorideinduced neuron apoptosis and expressions of inflammatory factors by activating microglia in rat brain. Mol Neurobiol 53: 4449-4460. https://doi.org/10.1007/s12035-015-9380-2.

Yong VW (2005) Metalloproteinases: mediators of pathology and regeneration in the CNS. Nat Rev Neurosci 6: 931-44. https://doi. org/10.1038/nrn1807

Yong VW, Krekoski CA, Forsyth PA, Bell R, Edwards DR (1998) Matrix metalloproteinases and diseases of the CNS. Trends Neurosci 21: 75-80. https://doi.org/https://doi.org/10.1016/S01662236(97)01169-7.

Yu WH, Woessner JFJ, McNeish J,D Stamenkovic I (2002) CD44 anchors the assembly of matrilysin/MMP-7 with heparin-binding epidermal growth factor precursor and ErbB4 and regulates female reproductive organ remodeling. Genes Dev 16: 307-323. https://doi. org/10.1101/gad.925702.

Zambuzzi WF, Paiva KBS, Menezes R, Oliveira RC, Taga R, Granjeiro JM (2009) MMP-9 and CD68+ cells are required for tissue remodeling in response to natural hydroxyapatite. J Mol Histol 40: 301-309. https://doi.org/10.1007/s10735-009-9241-2. 